\title{
Pemanfaatan Digital Marketing dan Pengelolaan Keuangan Pada Toko Bahan Kue
}

\author{
Ni Luh Ratniasih ${ }^{\mathrm{a}, 1, *}$, Dwi Haryadi Nugraha ${ }^{\mathrm{b}, 2}$ \\ a,b Fakultas Informatika dan Komputer, ITB STIKOM Bali, Denpasar \\ ${ }^{1}$ ratni@stikom-bali.ac.id *; ${ }^{2}$ dwiharyadinugraha@yahoo.com \\ * corresponding author
}

ARTICLE INFO

Keywords

Cake Shop;

Digital Marketing;

Financial Management

\begin{abstract}
Competition in the cake and bread business is quite tight, this is marked by the emergence of the same business, and the increasing variety of breads and cakes offered. The development of culinary business is also seen from the number of shops opened baking cake ingredients. Partners in this service activity are a cake ingredients shop and sell pastries located in the Denpasar city market area. The name of the partner shop is "Annika Shop" which is located at Jalan Trenggana, No. 2 Penatih, East Denpasar. The shop owner named Ibu $\mathrm{Ni}$ Gusti Ayu Anggreni is assisted by 2 employees. In this service activity, the partner's problem handled is the lack of maximum product marketing and financial management activities are not carried out so that the loss / profit of the business can be less known and measured. From these main problems, a solution to this community service is provided, namely training in the use of digital marketing to introduce business to the wider community and financial management training. Achievement indicators are able to introduce business partners to the wider community so as to increase partner income up to $50 \%$ from before the training. Able to increase the ability and knowledge of partners in financial management up to $100 \%$.
\end{abstract}

\section{PENDAHULUAN}

Toko Annika merupakan mitra dalam kegiatan pengabdian ini. Toko Annika adalah sebuah toko penyedia bahan kue dan menjual kue kering yang beralamat di Jalan Trenggana, No 2 Penatih, Denpasar Timur. Pemilik toko bernama Ibu Ni Gusti Ayu Anggreni yang dibantu oleh 2 orang karyawan. Barang yang dijual di toko adalah bahan bahan utama kue seperti berbagai jenis tepung, gula pasir, gula aren, minyak goreng, mentega, coklat cair dan padat, plastik kemasan kue dengan berbagai ukuran dan minuman yang jual grosir atau eceran. Toko Annika juga menjual kue kering seperti bolu kukus dan donat yang diproduksi sendiri oleh Ibu Ni Gusti Ayu Anggreni.

Berdasarkan hasil wawancara dan berkunjung langsung ke tempat mitra, diperoleh informasi bahwa permintaan untuk kue kering menurun yang sebelumnya perhari produksi kue bolu 10 sampai 20 loyang/hari sekarang menjadi 5 sampai 10 loyang/hari. Hal ini dikarenakan kurang maksimalnya upaya untuk melakukan pemasaran produk oleh mitra, dimana pemasaran hanya dilakukan dengan menunggu customer datang ke toko atau rekomendasi dari para pembeli. Selain itu, pada saat wawancara mitra tidak dapat menyebutkan dengan pasti keuntungan dan kerugian setiap bulannya, mitra hanya mampu memperkirakan saja keuntungan setiap bulannya. Hal ini dikarenakan pengelolaan keuangan tidak dilakukan dengan baik. Pencatatan transaksi di toko hanya dilakukan 
dengan menulis barang - barang yang terjual seperti yang terlihat pada Gambar 1, tanpa mencatat pengeluaran toko setiap harinya.

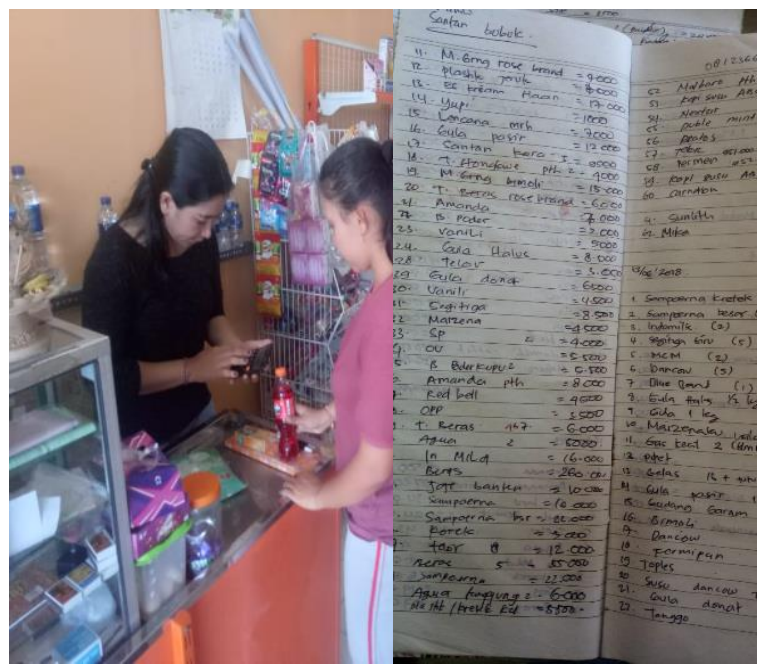

Gambar 1. Pencatatan Transaksi

Berdasarkan analisis situasi yang dilakukan, permasalah prioritas yang dihadapi oleh mitra yaitu (1) pemasaran produk bahan kue dan kue hanya dilakukan melalui toko tanpa memanfaatkan teknologi internet, sehingga kurang maksimal menjaring customer yang dijadikan target. (2) Mitra tidak melakukan pengelolaan keuangan dengan baik sehingga tidak mengetahui rugi/laba setiap tahunnya, hal ini dikarenakan mitra tidak memiliki pengetahuan yang cukup dalam melakukan pengelolaan keuangan. Berdasarkan permasalahan yang dihadapi mitra, maka dalam kegiatan pengabdian masyarakat ini, solusi yang dapat ditawarkan adalah sebagai berikut (1) pelatihan pemanfaataan digital marketing untuk mengetahui teknik - teknik memanfaatkan teknologi internet dan media elektronik untuk memperluas pemasaran suatu produk atau brand dan meningkatkan pendapatan mitra. Digital marketing dengan memanfaatkan facebook. (2) Pelatihan pengelolaan keuangan sehingga meningkatkan kemampuan mitra dalam melakukan pencatatan pengeluaran dan pemasukan serta dapat mengetahui rugi/laba usaha setiap tahunnya.

\section{PELAKSAAAN DAN METODE}

Lokasi pengabdian terletak di Jalan Trenggana, No 2 Penatih, Denpasar Timur. Jarak antara lokasi pelaksana dan mitra adalah kurang lebih $10 \mathrm{Km}$. Terdapat empat tahap rencana kerja dalam kegiatan pengabdian ini yaitu tahap pertama adalah sosialisasi kegiatan kepada mitra, tahap kedua adalah pelatihan pemanfaatan digital marketing, tahap ketiga adalah pelatihan pengelolaan keuangan kepada mitra dan tahap terakhir adalah monitoring dan evaluasi kegiatan untuk mengetahui tingkat keberhasilan kegiatan pengabdian. Prosedur kerja kegiatan pengabdian ini dapat digambarkan seperti rencana kegiatan yang dapat dilihat pada Gambar 2. Kegiatan sosialisasi memiliki tujuan untuk menyamakan persepsi tujuan kegiatan antara pelaksana pengabdian dan mitra. Kegiatan sosialisasi dilakukan dengan memberikan informasi kepada mitra tentang kegiatan pengabdian masyarakat yang akan dilaksanakan. Memberikan pemahaman kepada mitra tentang latar belakang kegiatan dan tujuan kegiatan. Sosialisasi diberikan oleh tim pengusul yang melibatkan pemilik UMKM dengan cara duduk bersama. Dokumentasi kegiatan ini berupa foto kegiatan sosialisasi dan video dibantu oleh tim mahasiswa. Pelatihan pemanfaatan digital marketing merupakan sebuah usaha memasarkan produk/bisnis dengan menggunakan perangkat elektronik/internet dengan beragam taktik 
marketing dan media digital bukan hanya untuk meningkatkan penjualan, tapi juga termasuk promosi produk dan membina hubungan dengan pelanggan. Pelatihan pemanfaatan digital marketing akan memanfaatkan tool yang disediakan oleh media sosial (facebook). Pelatihan digital marketing diberikan kepada 4 orang peserta yang terdiri dari pemilik dan karyawan mitra dengan metode ceramah dan praktek langsung. Dokumentasi kegiatan berupa foto dan video dibantu oleh tim mahasiswa. Kegiatan pelatihan pengelolaan keuangan akan memberikan pelatihan pengelolaan keuangan secara sederhana dengan pencatatan pemasukan dan pengeluaran mitra pada buku besar. Hal ini dilakukan agar mitra memahami cara mencatat kas masuk dan keluar serta dapat membuat report laporan keuangan setiap bulannya. Peserta pelatihan berjumlah 4 orang yang terdiri dari pemilik dan karyawan mitra dengan metode ceramah dan praktek langsung. Dokumentasi kegiatan berupa foto dan video dibantu oleh tim mahasiswa.

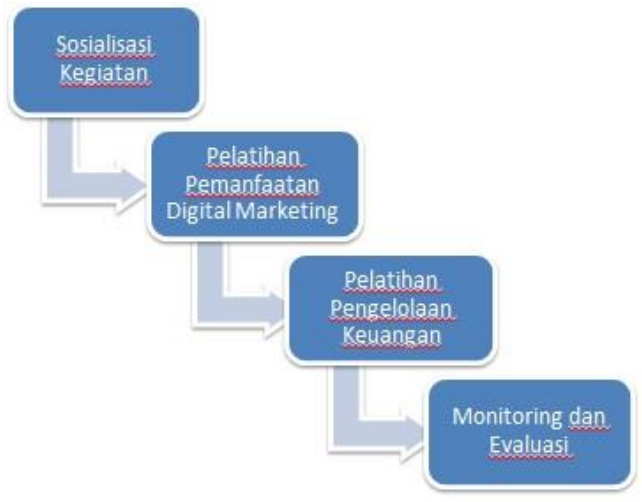

Gambar 2. Rencana Kerja Kegiatan

\section{HASIL DAN PEMBAHASAN}

Kegiatan pengabdian pada Toko Annika dilakukan dalam beberapa tahap sesuai dengan rencana kegiatan. Terdapat empat tahap kegiatan dalam pengabdian ini yaitu tahap pertama adalah sosialisasi kegiatan kepada mitra, tahap kedua adalah pelatihan pemasaran online, tahap ketiga adalah pelatihan manajemen keuangan, dan tahap keempat adalah monitoring dan evaluasi kegiatan untuk mengetahui tingkat keberhasilan kegiatan pengabdian.

\section{Kegiatan Sosialisasi}

Kegiatan sosialisasi dilakukan pada bulan November 2019. Materi sosialisasi diberikan oleh Ni Luh Ratniasih dan Dwi Haryadi Nugraha serta didampingi oleh mahasiswa dimana sosialisasi dilakukan dengan pemilik usaha Toko Annika yaitu Ibu I Gst Ayu Angreni untuk menyampaikan bahwa kegiatan pengabdian masyarakat telah diterima dan dibiayai. Pada pertemuan tersebut telah disampaikan informasi - informasi mengenai latar belakang, target, sasaran dan tujuan kegiatan. Indikator - indikator tersebut memiliki satu tujuan prinsip, yaitu meningkatkan kesejahteraan mitra serta meningkatkan pengetahuan mitra dalam memasarkan produk secara online. Kegiatan sosialisasi dilakukan dengan cara diskusi dan tanya jawab serta dilakukan dokumentasi kegiatan.

\section{Pelatihan Pemanfaatan Digital Marketing}

Pelatihan pemanfaatan digital marketing dengan menggunakan facebook sebagai media pemasaran online dilakukan beberapa kali dalam satu bulan Desember 2019. Kegiatan ini 
diikuti oleh 3 orang peserta yang terdiri dari pemilik dan karyawan Toko Annika. Materi pemasaran online diberikan oleh Ni Luh Ratniasih dengan cara praktek langsung dan diskusi, salah satu dokumentasi pelatihan dapat dilihat pada Gambar 3.

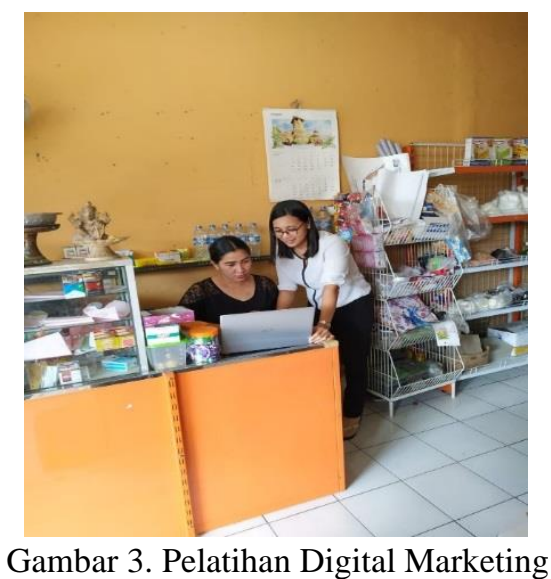

Kegiatan yang dilakukan dalam pelatihan ini yaitu mempelajari sosial media. Instruktur memperkenalkan sosial media facebook sebagai contoh. Peserta diajarkan membuat membuat account facebook sampai mengoperasikan facebook untuk menjual dan meneriama pesanan secara online. Hasil pelatihan pemanfaatan teknologi informasi untuk pemasaran adalah account facebook yang terlihat pada Gambar 4.

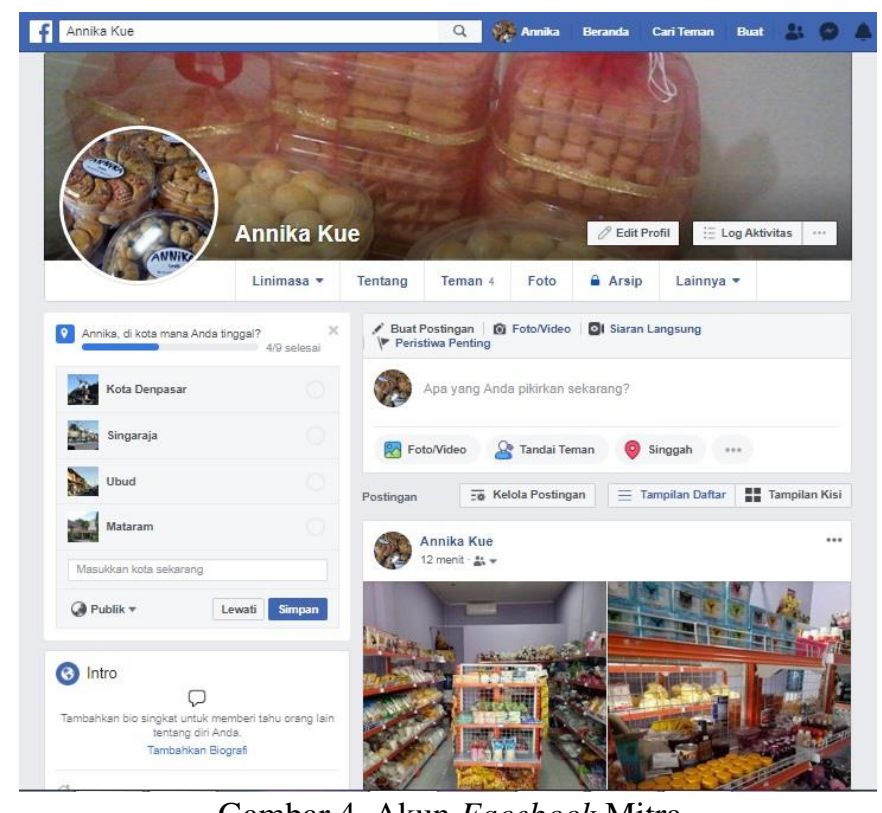

Gambar 4. Akun Facebook Mitra

Materi yang disampaikan pada saat pelatihan pemanfaatan teknologi informasi untuk pemasaran produk adalah bagaimana langkah - langkah mendaftar facebook dan fitur - fitur pada facebook.

\section{Pelatihan Manajemen Keuangan}

Kegiatan pelatihan manajemen keuangan adalah memberikan pelatihan manajemen keuangan secara sederhana dengan pencatatan pemasukan dan pengeluaran mitra pada buku besar. Pada pelatihan ini juga diperkenalkan pemanfaatan Microsoft Excel dalam pencatatan transaksi. Kegiatan pelatihan ini diikuti oleh para peserta yang sama dengan pelatihan sebelumnya yaitu berjumlah 2 orang peserta yang terdiri dari pemilik dan karyawan Toko Annika. Pada pelatihan ini instruktur mengajarkan bagaimana membuat 
sebuah kolom pada Microsoft Excel dan pembuatan form pencatatan keuangan atau pembukuan. Pada pelatihan ini, para peserta belajar untuk melakukan rekapitulasi pengeluaran, pemasukan dan data kas lainnya. Hasil pelatihan pada kegiatan pelatihan Microsoft Excel untuk manajemen keuangan dapat dilihat pada Gambar 5 berikut ini :

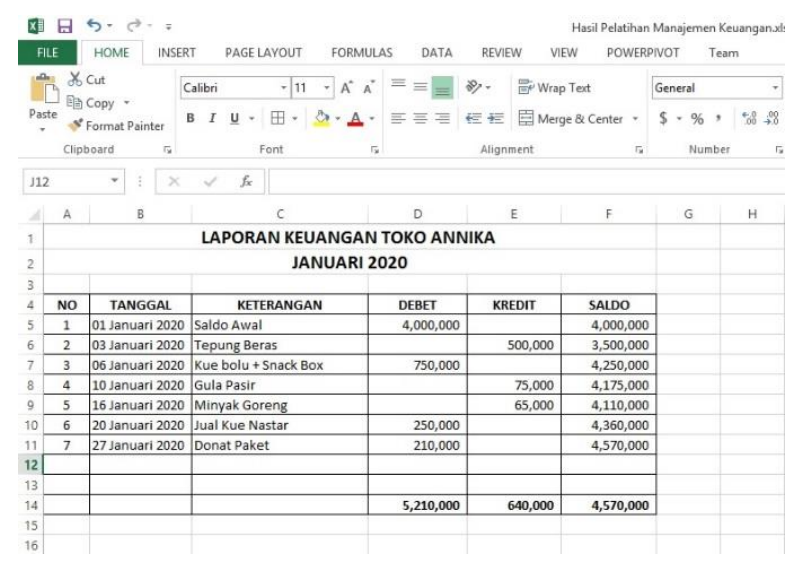

Gambar 5. Hasil Pelatihan Manajemen Keuangan

Pada pelatihan ini para peserta diajarkan membuat kolom serta rumus - rumus yang dapat dipergunakan pada Microsoft Excel seperti yang terlihat pada Gambar 6. Terdapat dokumentasi pada saat pelatihan manajemen dapat dilihat pada Gambar 7 .

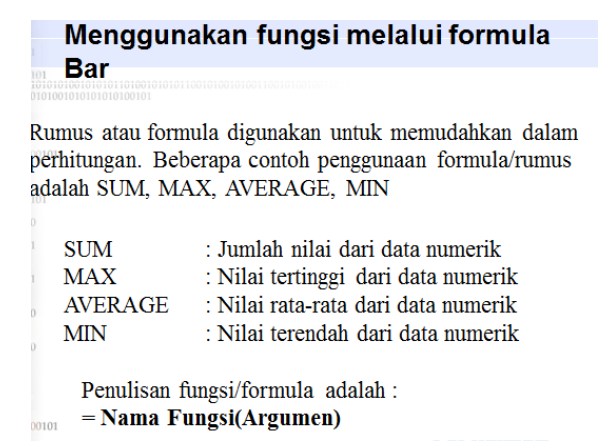

Gambar 6. Formula dalam Microsoft Excel

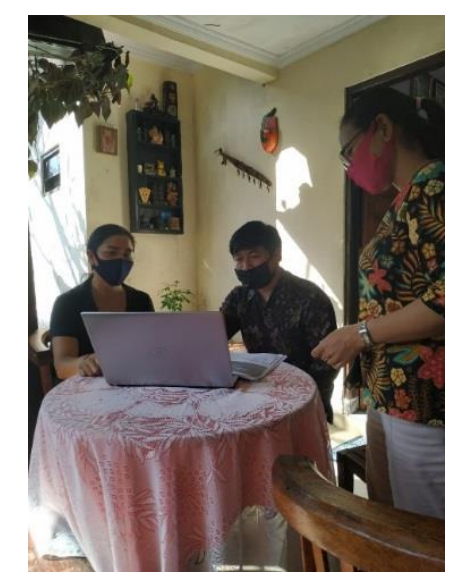

Gambar 7. Pelatihan Manajemen Keuangan

Berdasarkan hasil monitoring dan evaluasi, luaran kegiatan pengabdian masyarat berdarkan target capaian kegiatan mampu menambah konsumen melalui media pemasaran 
online sehingga meningkatkan pendapatan mitra. Luaran kegiatan dapat dilihat pada Tabel1.

\begin{tabular}{|c|c|c|c|c|}
\hline \multicolumn{5}{|c|}{ Tabel 1. Luaran Kegiatan } \\
\hline No & Kegiatan & Sebelum & Sesudah & Peningkatan \\
\hline 1 & $\begin{array}{l}\text { Meningkatkan } \\
\text { jumlah produksi } \\
\text { mitra. }\end{array}$ & $\begin{array}{l}\text { Jumlah produksi } \\
\text { kue } 5-10 \text { kue } \\
\text { kering dalam } 1 \\
\text { minggu }\end{array}$ & $\begin{array}{l}\text { Jumlah produksi } \\
\text { kue } 10-20 \text { kue } \\
\text { kering dalam } 1 \\
\text { minggu }\end{array}$ & $\begin{array}{l}50 \% \\
\text { Peningkatan } \\
\text { jumlah } \\
\text { produksi }\end{array}$ \\
\hline 2 & $\begin{array}{l}\text { Memperluas } \\
\text { jaringan } \\
\text { pemasaran }\end{array}$ & $\begin{array}{l}\text { Pemasaran } \\
\text { hanya } 1 \text { media } \\
\text { yaitu menunggu } \\
\text { pembeli datang } \\
\text { ke toko }\end{array}$ & $\begin{array}{lr}\text { Pemasaran } & \text { dan } \\
\text { penjualan } & 2 \\
\text { media } & \text { yaitu } \\
\text { toko } & \text { dan } \\
\text { melalui } & \text { media } \\
\text { sosial } & \\
\text { (facebook). } & \end{array}$ & $\begin{array}{l}50 \quad \% \\
\text { Peningkatan } \\
\text { pemasaran }\end{array}$ \\
\hline 3 & $\begin{array}{l}\text { Meningkatkan } \\
\text { pendapatan } \\
\text { Mitra }\end{array}$ & $\begin{array}{l}8.000 .000 \text { s.d } \\
10.000 .000 / \mathrm{bln}\end{array}$ & $\begin{array}{l}15.000 .000 \text { s.d } \\
20.000 .000 / \mathrm{bln}\end{array}$ & $\begin{array}{l}50 \% \\
\text { peningkatan } \\
\text { pendapatan }\end{array}$ \\
\hline 4 & $\begin{array}{l}\text { Meningkatakan } \\
\text { pengetahuan } \\
\text { mitra dalam } \\
\text { manajemen } \\
\text { keuangan }\end{array}$ & $\begin{array}{lr}\text { Dari } 4 \text { orang } \\
\text { peserta } \\
\text { pelatihan } \\
\text { orang yang } \\
\text { memahami } \\
\text { manajemen } \\
\text { keuangan }\end{array}$ & $\begin{array}{lr}\text { Dari } 4 \text { orang } \\
\text { peserta } \\
\text { pelatihan } 4 \\
\text { orang yang } \\
\text { memahami } \\
\text { manajemen } \\
\text { keuangan }\end{array}$ & $\begin{array}{l}100 \quad \% \\
\text { meningkataka } \\
\text { n pengetahuan } \\
\text { mitra dalam } \\
\text { manajemen } \\
\text { keuangan }\end{array}$ \\
\hline
\end{tabular}

\section{SIMPULAN}

Berdasarkan kegiatan pengabdian yang telah berlangsung maka dapat diambil beberapa kesimpulan yaitu : (1) Kegiatan yang telah dilakukan adalah sosialisasi kegiatan, pemanfaatan digital marketing melalui pemanfaatan teknologi untuk pemasaran produk, pelatihan manajemen keuangan, dan monitoring evaluasi. (2) Beberapa target dan luaran dari kegiatan ini telah tercapai yaitu adanya peningkatan pengetahuan UKM dalam pemanfaatan digital marketing untuk pemasaran produk seperti facebook, meningkatnya pendapatan mitra hingga $50 \%$, dan meningkatakan pengetahuan mitra dalam manajemen keuangan hingga $100 \%$

\section{SARAN}

Mengingat besarnya manfaat kegiatan pengabdian pada masyarakat ini, maka selanjutnya perlu : (1) Mengadakan pelatihan serupa pada usaha kecil dan menengah lain baik yang bergerak dalam bidang yang sama maupun bidang lainnya. (2) Adanya kesinambungan dan monitoring program pasca kegiatan pengabdian ini sehingga para peserta benar - benar dapat mempraktekan pengetahuan yang didapat setelah melakukan pelatihan.

\section{UCAPAN TERIMA KASIH}

Ucapan terima kasih kepada lembaga Penelitian dan Pengabdian Masyarakat ITB STIKOM Bali, kepada UKM yang mendukung terlaksananya kegiatan pengabdian dengan baik dan lancar, serta kepada pihak yang memberikan gagasan, saran, masukan serta pandangan terhadap penyusunan artikel pengabdian ini. 


\section{DAFTRA PUSTAKA}

Suryana. 2010. Kewirausahaan, Pedoman Praktis : Kiat dan Proses Menuju Sukses. Jakarta: Salemba Empat.

Sunarti.Sunari, Puspita.Rani Herning, Ernawati.Rini, "Pengembangan Pemasaran Usaha Kecil Kue Tradisional Rumahan Melalui Media E-Commerce,” Abdimas Mahakam Journal, vol.2, no. 2, Juni 2018.

Chan, CL. 2015. Analisis Pelatihan Manajerial pada PT. Mitra Pinasthika Mulia Surabaya. Jurnal Agora, 3 (1).

David, F. R. (2009). Manajemenstrategi. Edisi Kesepuluh. Jilid 1. Jakarta: Salemba Empat.

Suryana. 2010. Kewirausahaan, Pedoman Praktis : Kiat dan Proses Menuju Sukses. Jakarta: Salemba Empat. 